\title{
Comparison of Behavior, Morphology and Morphometry of Equine and Canine Adipose Derived Mesenchymal Stem Cells in Culture
}

\author{
Comparación del Comportamiento, Morfología y Morfometría del Tejido Adiposo \\ Equino y Canino Derivado de Células Madre Mesenquimales en Cultivo
}

*Jakub Grzesiak; "Krzysztof Marycz; *Joanna Czogala; "Karol Wrzeszcz \& **Jakub Nicpoń

GRZESIAK, J.; MARYCZ, K.; CZOGALA, J.; WRZESZCZ, K. \& NICPOŃ, J. Comparison of behavior, morphology and morphometry of equine and canine adipose derived mesenchymal stem cells in culture. Int. J. Morphol., 29(3):1012-1017, 2011.

SUMMARY: Recent studies revealed multipotent properties of fat tissue isolated mesenchymal stem cells. These cells are successfully used as therapeutic factor for many locomotive disorders, being even more effective than stem cells from bone marrow. Isolated and cultured, AD-MSCs were observed, photographed and measured to compare cells from two different species.

KEY WORDS: AD-MSC; Behavior; Morphology; Morphometry.

\section{INTRODUCTION}

Stem cells could be characterized by several properties, which distinguish them from other cell types. Most of all, they are long-living cells with high self renewal capacity. Moreover, they have a potential to differentiate into diverse kinds of cells. Generally, two different kinds of stem cells are described: namely embryonic and adult cells (Ratajczak et al., 2008). Both of them have advantages and disadvantages, as far as their clinical utility is concerned. Despite embryonic stem cells (ES) have enormous proliferative and multilineage potential, they are unpredictable after application to the patient. On the other hand, mature stem cells have limited capability of differentiation, but instead, their development is easier to control. This group could be further divided into hematopoetic cells (eg. cord blood), and mesenchymal cells in most adult tissues, both of multipotential character. Recently, rising interest in mesenchymal stem cells (MSC) derived from adipose tissue autogenic transplantations, as a tool of regenerative medicine, has been observed. Fat tissue is easy obtainable source of these cells, in contrast to invasive collection methods from other tissues, such us bone marrow. It also has higher stem cell producing efficiency (Zhu et al., 2008).
The majority of MSC applications are autogenic in their nature, which eliminates adverse host reactions. In field of veterinary medicine, stem cell therapy is becoming more and more available. In dogs and horses diseases of the locomotor system, such as osteoarthritis, tendon and ligament injuries or immune mediated polyarthritis, many successes have been documented (Black et al., 2008; Gimble et al., 2007; Frisbie \& Smith, 2010). In this study, isolation and culturing of MSCs was performed. Stem cells have been observed with light and electron microscopy, with association of dyes or unstained. Based on these observations, comparison of morphology and morphometry of all animal cells coming from primary and secondary cultures was made.

\section{MATERIAL AND METHOD}

Isolation. White adipose tissue was obtained from five horses and six dogs suffering from orthopedic disorders (tendon tears, crucial ligament rapture, elbow dysplasia) with their owners permission. Equine fat was collected from tail

\footnotetext{
Electron Microscopy Laboratory, Department of Animal Hygiene, Faculty of Biology and Animal Science, Wroclaw University of Environmental and Life Sciences, Wroclaw, Poland.

** Department of Surgery, Faculty of Veterinary Medicine, Wroclaw University of Environmental and Life Sciences, Wroclaw, Poland.
} 
base area, whereas canine samples were obtained from inguinal region. Approximately 5 grams of tissue was dissected under aseptic conditions from each animal, under local anesthesia. Samples were placed into sterile Hank's Balanced Salt Solution (HBSS, Sigma) and transported immediately to the laboratory. Cell isolation included fine mincing by surgical scissors, washing in HBSS, resecting any visible blood traces and vessels; finally collagenase digestion was performed till solution became opaque (Zhu et al., 2008). Digestion buffer comprised with $0.2 \%$ collagenase type I (Sigma) dissolved in HBSS. After that, mixture was centrifuged in conical tube $1200 \mathrm{xg} / 10$ minutes (IEC CL31R, Thermo Scientific), and solution was separated into three layers, with nucleated cells located in the lowest one. Supernatant was removed, cell fraction was carefully collected and transferred to $25 \mathrm{ccm}$ T-flask with medium (DMEM + 10\%FBS + antibiotic solution, Sigma). Cells were cultured in humidified incubator (FDHI, Thermo Scientific) in $37^{\circ} \mathrm{C}, 5 \% \mathrm{CO}_{2}$ for six (dog) and fourteen days (horse). After cells almost reached confluency, they were washed twice in HBSS, trypsinized (0.2\% trypsin, Sigma) and incubated till the majority of them had detached from surface. Trypsin solution with suspended cells was collected, neutralized by complete medium addition, transferred into conical tube and centrifuged at $300 \mathrm{~g}$ for 5 minutes. Supernatant was discarded; cell pellet was resuspended and counted for total and alive cell yield with Thoma camara by trypan blue $(0.4 \%$, Sigma) staining. Afterwards, cells were split to desired density ( $5 \times 104$ cells/ml-1) and seeded in new T-flasks. Twenty passages were maintained.

Visualization. Microscopic observations and measurements were performed daily and of each passage of culture, by means of inverted contrast-phase microscope (AxioObserver A1, Zeiss; AxioImager 4.7, Zeiss). Also, semiconfluent primary and passaged cell cultures were fixed (in glutaraldehyde/osmium tetroxide), observed and measured in scanning electron microscope (Evo LS15, Zeiss). Photographic documentation and morphometry of canine and equine cells including all culture stages was conducted to compare shape and size of suspended cells, diameter of their nuclei, diameter of endosomal vesicles and range of perinuclear areas (Solanki, 2008). Thickness of cell layer was also measured (SE1, 1000x, profile width, Evo LS15 Zeiss). Immunocytochemistry stainings for CD44 (Novocastra, 1:200) and CD105 (Abcam, 1:200) antigens were also carried out. Additionally, Oil Red O (Sigma) staining was performed on primary and secondary cell cultures to investigate preadipocytes existence. Janus green $\mathrm{B}$ and methylene blue (Sigma) staining was conducted for mitochondria visualization.

\section{RESULTS}

In primary culture, the diversity of cells has been observed. Existence of stromal vascular fraction cells (SVF), namely MSCs, preadipocytes, fibroblasts, smooth muscle and endothelial cells was noticed. Additionally, hematopoietic cell fraction was observed, but contrary to aforementioned cells they had no adhesive properties. MSCs proliferated faster than others, so, after six days for dogs and fourteen days for horses, they were dominating population in culture. While first passage, about 3x106 alive cells have been detached and split to new vessels. Trypan blue staining confirmed almost $100 \%$ vitality. Dog fibroblast-like cells were similar to equine, which was confirmed by morphometry (t-test, $\mathrm{n}=100, \mathrm{p}=0.05$ ) (Table I). The only parameter that was different between canine and equine cells was nucleoli number.

\section{Cell behavior}

Primary culture. Equine individual cells, obtained by collagenase digestion, settled in a few spots (7-15) in T-flask $(25 \mathrm{ccm})$ as particular CFU (colony forming unit). Canine cells were acting similarly, although they exhibited adhesive properties to the surface earlier. Dividing cells were aiming toward other colonies. After colonies fusion, cells were creating storiform patterns, forming in wavelike bundles. Often, they accumulate in rounded clumps. This structure

Table I. Average measurements of canine and equine cell nucleuses, rounded cells, endosomal vehicles and cytoplasmic connections.

\begin{tabular}{lcccc}
\hline DOG & Nucleuses & $\begin{array}{c}\text { Not adherent } \\
\text { cells }\end{array}$ & Endosomes & $\begin{array}{c}\text { Intercellular } \\
\text { connections }\end{array}$ \\
\hline $\begin{array}{l}\text { Diameter }(\mu \mathrm{m}) \\
\text { Length }(\mu \mathrm{m})\end{array}$ & $\mathbf{1 6 , 2}$ & $\mathbf{2 2 , 3 5}$ & $\mathbf{0 , 7 1}$ & $\mathbf{2 0 , 6 4}$ \\
\hline HORSE & Nucleuses & $\begin{array}{c}\text { Not adherent } \\
\text { cells }\end{array}$ & Endosomes & $\begin{array}{c}\text { Intracellular } \\
\text { connections }\end{array}$ \\
\hline $\begin{array}{l}\text { Diameter }(\mu \mathrm{m}) \\
\text { Length }(\mu \mathbf{m})\end{array}$ & $\mathbf{1 6 , 4}$ & $\mathbf{2 2 , 4 2}$ & $\mathbf{0 , 7 2}$ & $\mathbf{2 0 , 7 7}$ \\
\hline
\end{tabular}


was growing so rapidly that clump surrounding cell layer has been broken (Fig. 1).

Secondary culture. Equine cell culture was nearly confluent after 14 days. Detached and transferred cells were suspended in medium, and after approximately one hour of incubation, they began to attach. They dispersed in regular way, to create one day after a net-like structure. The observed growth was relatively fast and population doubling time was about 24 hours. Cell distribution directly after passage was predominately scattered and random. After approximately 24 hours of incubation cell pattern could be described as storiform, similar to primary cultures, however they were distributed less rarely with free spaces between them. Process of cell division was morphologically different. Division of particular cells underwent in different planes (longitudinal, transversal). Some of daughter cells were spindle shaped and adherent to surface immediately, what was observed mainly in almost confluent cultures. On the other hand, in less dense cultures, another-round-shaped sub-population of daughter cells was observed.

\section{Cell morphology}

Primary culture. Particular stem cell morphology could be described as bi- or three-angled cells, with relatively high nuclear-cytoplasmic ratio. Animal cultured cells were spindle-shaped, with prominent nucleoli. Incidentally, cells with intracytoplasmatic abundant vacuoles with lipid content of different diameter, situated in perinuclear region, were noticed. Application of Oil Red O staining allowed confirming lipid nature of vacuole content. Even less frequent, about five times bigger than the rest and flattened cells, with irregular borders were found. They were characterized by multiple nuclei and foamy cytoplasm. As far as nucleoli number in concerned, most dog cells have one big and two small nucleoli while equine cells always exhibited two nucleoli of approximately equal size. Janus B green staining showed mitochondria presence and

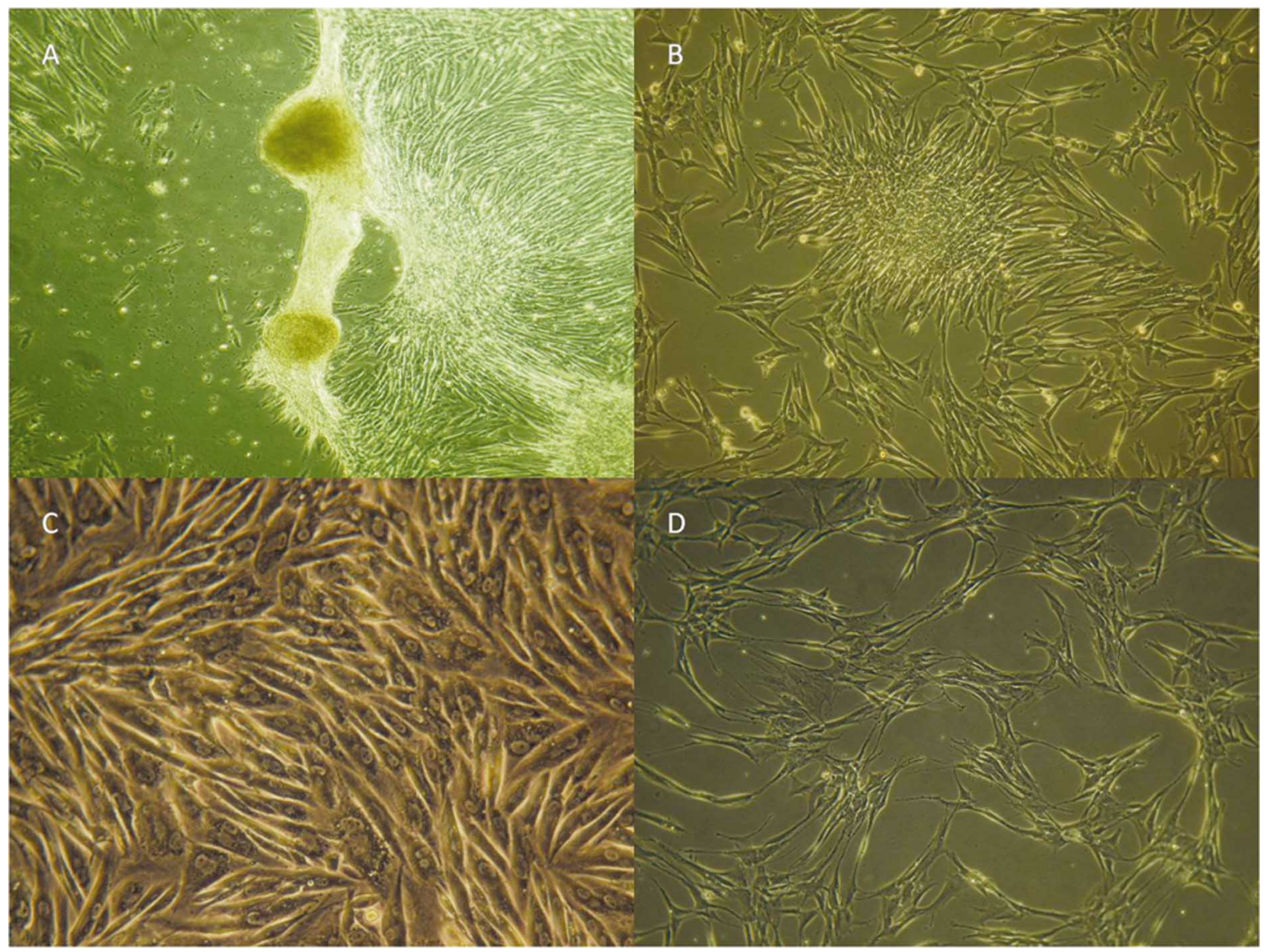

Fig. 1. Heterogeneity of MSCs growth patterns. A. Equine cell clumps in primary culture; contrast-phase microscopy, 10x. B. Equine cells after 3rd passage; contrast-phase microscopy, 10x. C. Canine MSCs growing tightly, forming bundles; contrast-phase microscopy, 20x. D. Canine MSCs after 3rd passage, forming net-like structure; contrast-phase microscopy, 10x. 
arrangement in examined cell population. Mitochondria were visible as green dots located at the periphery of individual cell.

Secondary culture. Just after seeding, cells were rounded, of gold-brown color when examined in inverted contrastphase microscope. First day after passage, morphology of cells changed, they were more flattened, and create long cytoplasmic connections with each other. Next day, cell morphology was uniform and they were spindle shaped again. Oil Red $\mathrm{O}$ staining has not displayed a presence of adipogenic precursors or adipocytes. Immunocytochemistry showed the presence of CD44 and CD105 antigens on cell surfaces. SEM techniques allowed visualizing more precisely the ultrastructure of examined cells. Not only nuclei with prominent nucleoli, but also mitochondria surrounding nucleus, and secretory granules within individual cells were observed. Contrast-phase microscopy with Janus Green B and methylene blue stain showed that mitochondria were localized pericentrically. Cell nuclei were comparable, including the nucleoli numbers. Everyday observations showed presence of endosomal vesicles in cell cytoplasm. They were mostly found in the perinuclear compartment, and just before cell division they migrate toward to opposite margins. In non-dividing cells, endoplasmic vesicles were intensively moving within the cell. After 19-20 passages, examined cells were less adhesive, more flattened and they were taking up more space. Intracytoplasmic lipid droplets appeared again, which was confirmed by means of Oil Red O method. Automatically, cell density decreased (down to $1,9 \times 106$ per flask). Their vitality also decreased, in means of trypan blue method (56\% vitality while eighteenth time passage).

Morphometry. Briefly, not adherent cells, nuclei, nucleoli and endosomal vehicles were measured, averaged and compared (Table I) (Fig. 2). Differences between species and passage numbers were not statistically significant.

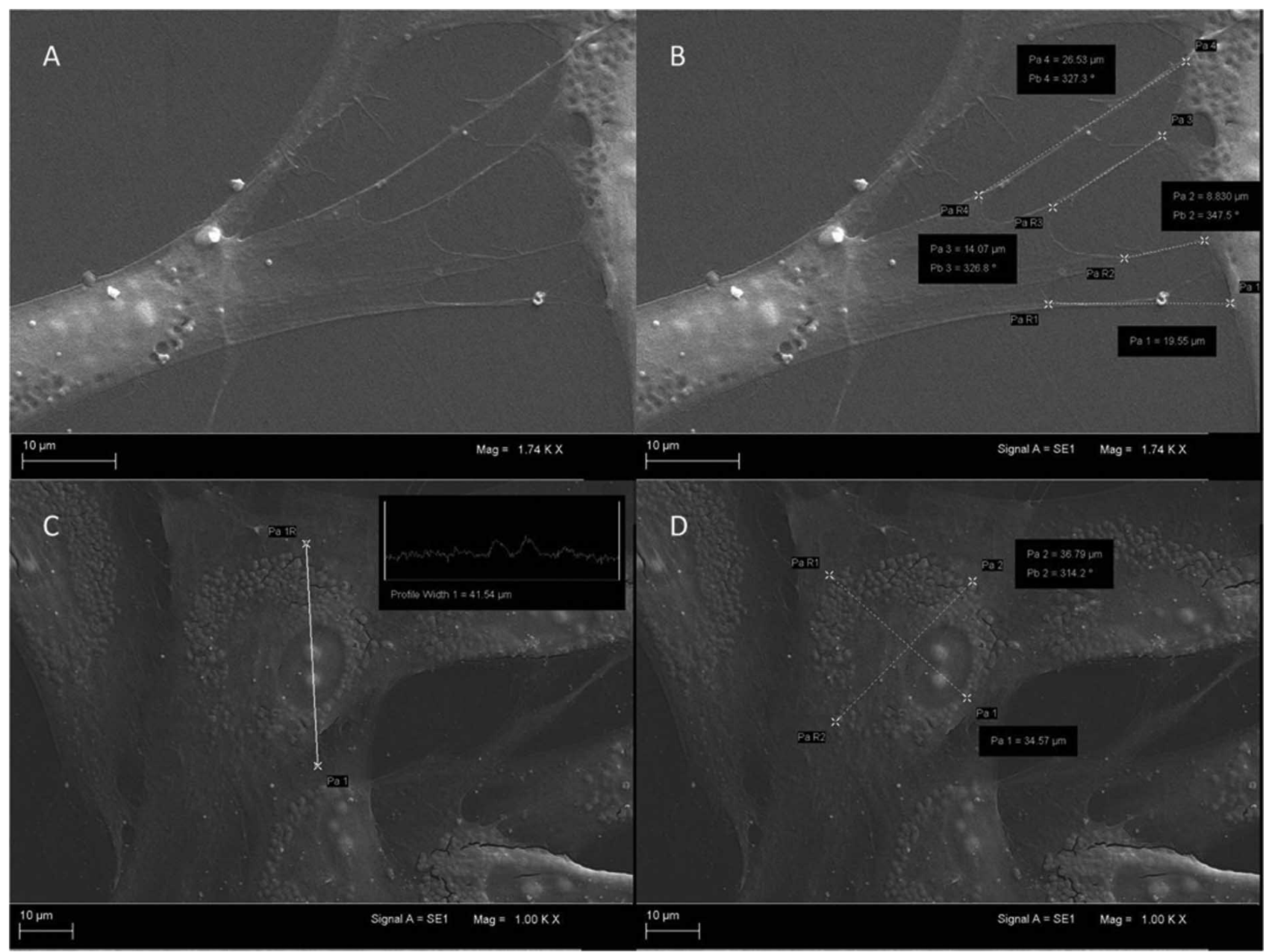

Fig. 2. Microphotographs and morphometric analysis of equine MSCs after 2nd passage. A. Microphotography of connection site between cells; SEM, SE1, 1740x. B. Morphometry of cytoplasmic connections; SEM, SE1, PL, 1000x. C. Morphometry of cell thickness in nuclear area; SEM, SE1, PW, 1000x. D. Morphometry of perinuclear area; SEM, SE1, PL, 1000x. 


\section{DISCUSSION}

Intensification of sport activity in horses, developmental musculoskeletal defects in rapidly growing dogs of large breed, and mechanical injuries very often lead to locomotive system diseases such as: tendon and ligament injuries, arthritis, osteoarthrosis, hip joint dysplasia etc. A novel branch of medicine, called regeneration medicine, began to develop more intensively in the last years (Nakagami et al., 2006).

Stem cell based therapies for animals have proved lately great therapeutic potential of mature progenitor cells. Clinical efficacy of bone marrow derived MSC (BMD-MSC) in animals are well documented. However, in the course of locomotive disorders, adipose derived MSC (AD-MSC) seems to give better results (Fresbie \& Smith). Recent studies defined adipose tissue as the most available and easy obtainable source of MSCs. Simplicity of collection is directly connected with main, undeniable advantage of ADMSC, which is non-invasive. Moreover, particular isolation from adipose tissue gives greater yield of proper stem cells, as this organ has an attribute of dynamic growth so it must have a large population of self-renewal, proliferative cells (Ward et al., 2010).

In this study, heterogeneous cell population from fat tissue was obtained, including MSCs, preadipocytes, fibroblasts, smooth muscle and endothelium cells, with significant MSCs domination (Zuk et al., 2002). During further investigations, special attention was put toward stem cells subpopulation. The main goal of this study was to show different morphological forms of aforementioned cells with diversity of visualization techniques. Contrast-phase microscopy analysis allowed visualizing the general dynamics of culture growth and behavior of particular cells. Observed storiform pattern of cell layer and their spindle shape, both in primary and secondary cultures, confirm their mesenchymal origin. Among multitude of MSCs, polynucleated, big cells were also spotted in primary cultures. They probably represent macrophage line, with phagocytic properties. Additionally, their common properties and antigen phenotype with preadipocytes is well documented (Charrière et al., 2003). Non-abundant cell population observed only in primary and late passages, with intracytoplasmic vacuoles, thanks to Oil Red O assays, could be defined as preadipocytes. Other (no MSC) type of cells, such as endothelium and hematopoetic ones, shortly after culture establishment, probably decayed without their specific growing factors and were absent at further culture stages.

Observations of cell morphophysiology showed endosomal vesicles actively migrating within the cell, what was particulary prominent at the early phase of growth. It could be consistent with high metabolic and mitotic status (Savage et al., 2007). In overconfluent cultures, decreased proliferation rate was noticed, which could be explained by contact inhibition (Krinner et al., 2010). Relatively big size of MSCs, their adhesive properties and improved observation tools allowed to examine and precisely measure them alive. The specific staining procedures (Oil Red O, Janus Green $\mathrm{B}$, methylene blue) applied created the opportunity to label more precisely presence and location changes of chosen cell organelles (lipid vacuoles, mitochondria, ribosomes). Interspecies comparison of dog and horse stem cells was conducted, but no significant differences were noticed. Morphology and morphometry of both species tend to be very similar, however further studies of this topic are needed.

GRZESIAK, J.; MARYCZ, K.; CZOGALA, J.; WRZESZCZ, K. \& NICPOŃ, J. Comparación del comportamiento, morfología y morfometría del tejido adiposo equino y canino derivado de células madre mesenquimales en cultivo. Int. J. Morphol., 29(3):1012-1017, 2011.

RESUMEN: Estudios recientes han revelado propiedades pluripotentes del tejido graso aislado de células madre mesenquimales. Estas células se utilizan con éxito como factor terapéutico para muchos trastornos locomotores, siendo aún más eficaz que las células madre de médula ósea. Aisladas y cultivadas, AD-MSC se observaron, fotografiaron y midieron comparar células de dos especies diferentes.

PALABRAS CLAVE: Tejido adiposo derivado de células madre mesenquimales; Comportamiento; Morfología; Morfometría.

\section{REFERENCES}

Black, L. L.; Gaynor, J.; Adams, C.; Dhupa, S.; Sams, D. E.; Taylor, R.; Harman, S.; Gingerich, D. A. \& Harman, R. Effect of intraarticular injection of autologous adipose-derived mesenchymal stem and regenerative cells on clinical signs of chronic osteoarthritis of the elbow joint in dogs. Vet. Ther., 9(3):192-200, 2008.

Charrière, G.; Cousin, B.; Arnaud, E.; André, M.; Bacou, F.; Pénicaud, L. \& Casteilla, L. Preadipocyte conversion to macrophage. J. Biol. Chem., 278(11):9850-5, 2003.

Fresbie, D. D. \& Smith, R. K. Clinical update on the use of mesenchymal stem cells in equine orthopaedics. Equine Vet. J., 42(1):86-9, 2010. 
Gimble, J. M.; Katz, A. J. \& Bunnel, B. A. Adipose-derived stem cells for regenerative medicine. Circ. Res., 100:1249-60, 2007.

Krinner, A.; Hoffman, M.; Loeffler, M.; Drasdo, D. \& Galle, J. Individual fates of mesenchymal stem cells in vitro. BMC Sys. Biol., 4:73, 2010.

Nakagami, H.; Morishita, R.; Madeda, K.; Kikuchi, Y.; Oginara, T. \& Kanaeda, Y. Adipose tissue-derived stromal cells as a novel option for regenerative cell therapy. J. Atheroscler. Thromb., 13(2):77-81, 2006.

Ratajczak, M. Z.; Zuba-Surma, E. K.; Wysoczyn'ski, M.; Wan, W.; Ratajczak, J.; Wojakowski, W. \& Kucia, M. Hunt for pluripotent stem cell - regenerative medicine search for almighty cell. J. Autoimmun., 30(3):151-62, 2008.

Savage, V. M.; Allen, A. P.; Brown, J. H.; Gillooly, J. F.; Herman, A. B.; Woodruff, W. H. \& West, G. B. Scaling of number, size and metabolic rate of cells with body size in mammals. Proc. Natl. Acad. Sci. US A, 104(11):4718-23, 2007.

Ward, M. G.; Adapala, J.; Adedokun, S. \& Ajuwon, K. Dynamic changes in extracellular matrix gene regulation in adipose tissue and impact on preadipocyte proliferation and apoptosis. FASEB J., 24:341.1, 2010.

Zhu, Y.; Liu, T.; Song, K.; Fan, X.; Ma, X. \& Cui, Z. Adiposederived stem cell: a better stem cell than BMSC. Cell Biochem. Funct., 26(6):644-75, 2008.

Zuk, P.; Zhu, M.; Ashjian, P.; De Ugarte, D. A.; Huang, J. I.; Mizuno, H.; Alfonso, Z. C.; Fraser, J. K.; Benhaim, P. \& Hedrick, M. H. Human adipose tissue is a source of multipotent stem cells. Mol. Biol. Cell, 13(12):4279-95, 2002.

\author{
Correspondence to: \\ Jakub Grzesiak \\ Electron Microscopy Laboratory \\ Department of Animal Hygiene \\ Faculty of Biology and Animal Science \\ Wroclaw University of Environmental and Life Sciences \\ Wroclaw \\ POLAND
}

Email: grzesiak.kuba@gmail.com

Received: 02-12-2010

Accepted: 27-01-2011 